\title{
Seed priming with hormones does not alleviate induced oxidative stress in maize seedlings subjected to salt stress
} \author{
Carolina Cristina Monteiro ${ }^{1}$, Ricardo Antunes Azevedo ${ }^{2 *}$ \\ ${ }^{1}$ USP/ESALQ - Programa de Pós-Graduação em Genética e Melhoramento de Plantas. \\ ${ }^{2}$ USP/ESALQ - Depto. de Genética, C.P. 09 - 13418-900 - Piracicaba, SP - Brasil. \\ *Correspondingauthor < raazeved@esalq.usp.br> \\ Edited by: Leonardo Oliveira Medici
}

Rogério Falleiros Carvalho ${ }^{1}$, Fernando Angelo Piotto ${ }^{1}$, Daiana Schmidt ${ }^{1}$, Leila Priscila Peters ${ }^{1}$,

\begin{abstract}
Seed priming with hormones has been an efficient method for increasing seed vigor as well as seedling growth under stressful conditions. These responses have in the past been attributed to the activation of antioxidant systems in a range of crops. The results described in this work show that hormonal priming with methyl jasmonate, salicylic acid or CEPA (chloroethylphosphonic acid), an ethylene (ET) releaser, does not induce the antioxidant activity of superoxide dismutase, catalase, ascorbate peroxidase or glutathione reductase in maize seedlings subjected to salt stress. The enhanced biomass of maize seedlings under salt stress that was observed only from ET priming indicates that the stress tolerance in maize from ethylene priming is a fundamental process for stress tolerance acquisition, which is explained, however, by other biochemical mechanisms but not by changes in the antioxidant system.
\end{abstract}

Keywords: Zea mays, antioxidant systems, hormonal pretreatment, salinity, seedling growth

\section{Introduction}

Environmental pollution is a major global problem, and plants are more and more subjected to a variety of abiotic stresses (Andrews et al., 2009; Cartes et al., 2010; Sarlikioti et al., 2010). Among these stresses, high concentrations of salt in the soil can result in severe detrimental factors, such as poor germination, seedling establishment and crop yield (Teklic et al., 2008; Bernstein et al., 2010; Soccio et al., 2010). This is mainly due to a low soil water potential and an imbalance in the uptake of mineral nutrients and their accumulation within the plant (Munns and Tester, 2008).

Seed priming (Figure 1) is an efficient method for increasing seed vigor and synchronization of germination, as well as the growth of seedlings of many crops under stressful conditions (Bajehbaj, 2010). In this process, one interesting approach into the question of the ameliorative effects of priming solutions on stress tolerance is that seed priming with hormones can also result in alleviated oxidative stress. For instance, seed priming with brassinosteroids (BR) increased peroxidase (POD), superoxide dismutase (SOD) and catalase (CAT) activities in Medicago sativa seedlings under salinity stress (Zhang et al., 2007). In Vicia faba, the improvement in salinity tolerance due to the application of SA during seed priming was associated with enhanced CAT, ascorbate peroxidase (APX), POD and glutathione reductase (GR) activities (Azooz, 2009). More recently, seeds of Agropyron elongatum primed with gibberellin (GA) and abscisic acid (ABA) exhibited induced CAT and SOD activities under drought conditions when compared to unprimed seeds (Eisvand et al., 2010). Maize (Zea mays L.) seeds primed with hormones, also exhibited acquired abiotic stress tolerance through a more responsive antioxidative system (Afzal et al., 2008; Farooq et al., 2008; Guan et al., 2009). However, little is known as how and which antioxidative mechanisms are involved in the acquisition of salt tolerance in maize following hormonal priming. Thus, in this study we have investigated specifically the effect of ET, methyl jasmonate (MeJA) and salicylic acid (SA) priming on the growth (fresh and dry weight) and antioxidant activity of four enzymes, SOD, CAT, APX and GR, of maize seedlings under salt stress.

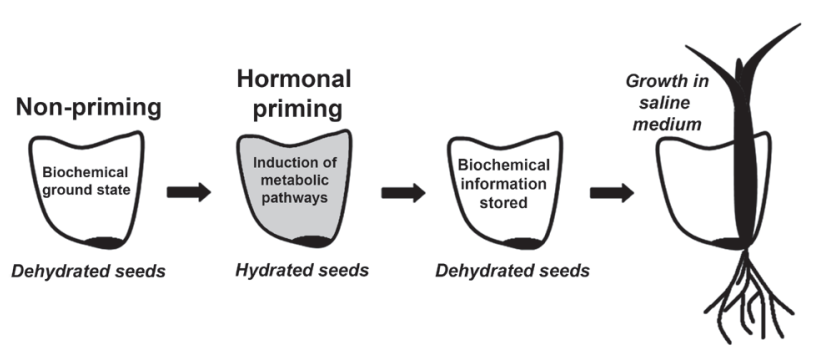

Figure 1 - Scheme of the experimental design for biochemical evaluation of aerial parts of maize seedlings under salt stress condition, following seed priming with hormones. The hydration treatment in hormonal solutions allows controlled imbibition and induction of pre-germinative metabolism (induction of metabolic pathways), but radicle emergence is prevented. The hydration treatment is stopped and the seeds allowed to air dry. During this step, the seeds "store" biochemical information that alleviates germination and growth under stress conditions (Finch-Savage and Leubner-Metzger, 2006). 


\section{Materials and Methods}

Seeds of the maize hybrid DKB 390 - DEKALB, which were previously surface sterilized with a fungicide mix [MAXIM XL: fludioxonil+metalaxyl- M $(0.038+0.015$, respectively, $\mathrm{g} \mathrm{kg}^{-1}$ of seeds)], were primed in solutions of 10 $\mathrm{mg} \mathrm{L} \mathrm{L}^{-1}$ CEPA-(chloroethylphosphonic acid), an ethylene releasing compound, $0.5 \mathrm{mM}$ methyl jasmonate (MeJA) or 0.5 $\mathrm{mM}$ salicylic acid (SA). Distilled-deionized water was used for the $\mathrm{H}_{2} \mathrm{O}$ treatment and non-primed (NP) seeds did not receive any initial priming treatment. Seeds (150 for each treatment) were primed separately in $250 \mathrm{~mL}$ of the hormonal solutions and water controls for $10 \mathrm{~h}$, at room temperature. After presoaking, seeds were surface dried on filter paper and then allowed to air dry for $48 \mathrm{~h}$ at $25^{\circ} \mathrm{C}$ (Iqbal and Ashraf, 2007).

Air-dried seeds following priming with hormones and water only and non-primed seeds were germinated on agar media $\left(6 \mathrm{~g} \mathrm{~L}^{-1}\right)$ containing no $\mathrm{NaCl}$ (control) or $30 \mathrm{mM} \mathrm{NaCl}$ (salt) (Figure 1). Shoots from five-day-old maize seedlings were weighed immediately to establish the fresh weight (FW) and the shoots were dried for $48 \mathrm{~h}$ at $70{ }^{\circ} \mathrm{C}$ in order to determine the dry weight (DW) and then stored at $-80{ }^{\circ} \mathrm{C}$ for further biochemical analysis. The seedling growth experiments were carried out in a controlled growth room at a temperature of $25{ }^{\circ} \mathrm{C}$ and a white light intensity of $55 \mu \mathrm{mol} \mathrm{m}{ }^{-2}$ $\mathrm{s}^{-1}$ with a $16 \mathrm{~h}$ photoperiod.

Lipid peroxidation was determined by estimating the content of thiobarbituric acid reactive substances (TBARS) following the method of Heath and Packer (1968). Shoots were used for TBARS analysis and extraction was carried as described by Gomes-Júnior et al. (2006a). The concentration of malondialdehyde (MDA) equivalents was calculated using an extinction coefficient of $1.55 \times 10^{-5} \mathrm{~mol}^{-1} \mathrm{~cm}^{-1}$.

The content of $\mathrm{H}_{2} \mathrm{O}_{2}$ was determined using the method described by Alexieva et al. (2001). Shoots were homogenized in $0.1 \%(\mathrm{w} / \mathrm{v})$ trichloroacetic acid (TCA). The homogenate was centrifuged at $12,000 \mathrm{~g}$ for $15 \mathrm{~min}$ at $4{ }^{\circ} \mathrm{C}$, and $200 \mu \mathrm{L}$ of the supernatant was added to $200 \mu \mathrm{L} 100$ $\mathrm{mM}$ potassium phosphate buffer $(\mathrm{pH} 7.0)$ and $800 \mu \mathrm{L}$ of 1 M KI. The absorbance was read at $390 \mathrm{~nm}$. A solution of $\mathrm{H}_{2} \mathrm{O}_{2}$ was used as a standard.

Fo extraction and analysis of antioxidant enzymes, the following steps were carried out at $4{ }^{\circ} \mathrm{C}$ unless stated otherwise. Shoots were homogenized (2:1, buffer volume : fresh weight) in a mortar with a pestle in $100 \mathrm{mM}$ potassium phosphate buffer ( $\mathrm{pH} 7.5$ ) containing $1 \mathrm{mM}$ ethylenediaminetetraacetic acid (EDTA), $3 \mathrm{mM}$ DL-dithiothreitol and $5 \%$ (w/v) insoluble polyvinylpolypyrrolidone (Gratão et al., 2008). The homogenate was centrifuged at $10,000 \mathrm{~g}$ for $30 \mathrm{~min}$, and the supernatant was stored in separate aliquots at $-80{ }^{\circ} \mathrm{C}$ prior to enzymatic analysis.

CAT activity was assayed spectrophotometrically at $25{ }^{\circ} \mathrm{C}$ in a reaction mixture containing $1 \mathrm{~mL} 100 \mathrm{mM}$ potassium phosphate buffer ( $\mathrm{pH} 7.5$ ) and $2.5 \mu \mathrm{L} \mathrm{H}_{2} \mathrm{O}_{2}$ (30\% solution), prepared immediately before use. The reaction was initiated by the addition of $15 \mu \mathrm{L}$ of plant extract, and the activity was determined by monitoring the removal of $\mathrm{H}_{2} \mathrm{O}_{2}$ at 240 nm over one minute against a plant extract-free blank (Gomes-Júnior et al., 2007). CAT activity is expressed as $\mu \mathrm{mol} \mathrm{min}^{-1} \mathrm{mg}^{-1}$ protein.

GR activity was assayed spectrophotometrically at $30{ }^{\circ} \mathrm{C}$ in a mixture containing $3 \mathrm{~mL} 100 \mathrm{mM}$ potassium phosphate

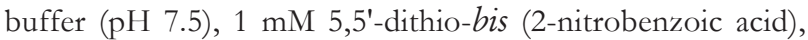
$1 \mathrm{mM}$ oxidized glutathione (GSSG) and $0.1 \mathrm{mM} \mathrm{NADPH}$. The reaction was initiated by the addition of $50 \mu \mathrm{L}$ of enzyme extract. The rate of reduction of GSSG was followed by monitoring the increase in absorbance at $412 \mathrm{~nm}$ over 2 min (Gomes-Júnior et al., 2006b). GR activity is expressed as $\mu \mathrm{mol} \mathrm{min}^{-1} \mathrm{mg}^{-1}$ protein.

APX activity was determined by monitoring the rate of ascorbate oxidation at $290 \mathrm{~nm}$ at $30{ }^{\circ} \mathrm{C}$. The reaction was initiated by the addition of $40 \mu \mathrm{L}$ of plant extract to $1 \mathrm{~mL}$ of a medium containing $50 \mathrm{mM}$ potassium phosphate buffer ( $\mathrm{pH} 7.0$ ), $0.5 \mathrm{mM}$ ascorbate, $0.1 \mathrm{mM}$ EDTA and $0.1 \mathrm{mM} \mathrm{H}_{2} \mathrm{O}_{2}$. APX activity, expressed as nmol ascorbate $\mathrm{min}^{-1} \mathrm{mg}^{-1}$ protein was calculated using the extinction coefficient $2.8 \mathrm{mM}^{-1} \mathrm{~cm}^{-1}$ for ascorbate (Nakano and Asada, 1981).

The activity of SOD was assayed following the method of Giannopolitis and Ries (1977) by measuring the ability of the enzyme to inhibit the photochemical reduction of nitroblue tetrazolium (NBT). The reaction solution $(3 \mathrm{~mL})$ contained $75 \mu \mathrm{M}$ NBT, $2 \mu \mathrm{M}$ riboflavin, $13 \mathrm{mM}$ methionine, $0.1 \mathrm{mM}$ EDTA, $50 \mathrm{mM}$ phosphate buffer $(\mathrm{pH} 7.8)$ and $30 \mu \mathrm{L}$ enzyme extract. The reaction solution maintained in a glass test tube was irradiated under light $(15 \mathrm{~W}$ fluorescent lamp) for 5 min. Enzyme activity was determined spectrophotometrically at $560 \mathrm{~nm}$ and expressed as SOD units $\mathrm{mg}^{-}$ ${ }^{1}$ protein. The protein content was determined by the method of Bradford (1976) using bovine serum albumin as a standard.

The experimental design was carried out with 12 seedlings in three replicate pots (agar medium), and the results are expressed as means and standard errors of the mean $( \pm$ SEM) of three independent replicate enzyme assays of each extract for TBARS and $\mathrm{H}_{2} \mathrm{O}_{2}$ contents and CAT, GR, APX and SOD activities. Shoot fresh and dry weights were analyzed from twenty individual seedlings per treatment. Data were submitted to variance analysis (ANOVA) and the means compared by the Tukey test $(p<0.05)$ using R software (URL http:/ /www.r-project.org).

\section{Results and Discussion}

Reductions in the FW and DW of the shoots were detected in all seedlings following growth in $30 \mathrm{mM} \mathrm{NaCl}$, indicating the onset of salt stress (Table 1). Priming treatment with MeJA caused a considerable reduction in both the DW and FW, irrespective of whether the seedlings were grown in $30 \mathrm{mM} \mathrm{NaCl}$. On the other hand, ET priming resulted in a small reduction in both DW and FW in salt treatment (Table 1), since the means were not different than both means from priming with water or ET, grown under the control condition without salt. ET priming triggers important tolerance mechanisms during seedling establishment under salt stress. Although ET precursor (1-aminocyclopropane-1- 
Table 1 - Shoot fresh weight (FW) and dry weight (DW) of maize seedlings germinated under salt stress conditions ( $30 \mathrm{mM} \mathrm{NaCl}$ ) following hormone treatment ${ }^{2,3,4}$ of the seeds. Controls are seedlings germinated in water only. The values represent the mean of 20 plants (mg per plant) \pm SEM.

\begin{tabular}{llccccc}
\hline & & \multicolumn{1}{c}{$\mathrm{NP}^{1}$} & $\mathrm{H}_{2} \mathrm{O}$ & $\mathrm{CEPA}^{2}$ & $\mathrm{MeJA}^{3}$ & $\mathrm{SA}^{4}$ \\
\hline \multirow{2}{*}{ FW } & Control & $172.54 \pm 12.69 \mathrm{ab}$ & $196.19 \pm 13.49 \mathrm{a}$ & $197.59 \pm 11.93 \mathrm{a}$ & $127.26 \pm 6.82 \mathrm{bc}$ & $184.98 \pm 14.26 \mathrm{a}$ \\
& Salt & $128.99 \pm 8.32 \mathrm{bc}$ & $133.87 \pm 5.83 \mathrm{bc}$ & $162.09 \pm 6.54 \mathrm{ab}$ & $98.60 \pm 6.54 \mathrm{c}$ & $138.10 \pm 9.50 \mathrm{bc}$ \\
\hline \multirow{2}{*}{ DW } & Control & $16.85 \pm 0.99 \mathrm{abc}$ & $18.60 \pm 0.96 \mathrm{a}$ & $18.60 \pm 0.80 \mathrm{a}$ & $12.84 \pm 0.51 \mathrm{de}$ & $18.01 \pm 0.92 \mathrm{ab}$ \\
& Salt & $13.86 \pm 0.67 \mathrm{cde}$ & $14.35 \pm 0.46 \mathrm{cde}$ & $16.04 \pm 0.48 \mathrm{abcd}$ & $11.14 \pm 0.58 \mathrm{e}$ & $14.69 \pm 0.74 \mathrm{bcd}$ \\
\hline
\end{tabular}

${ }^{1}$ Non primed, ${ }^{2}$ chloroethylphosphonic acid, ${ }^{3}$ methyl jasmonate, ${ }^{4}$ salicylic acid. Distinct letters (a, b, c, d and e) indicate differences among treatments (Tukey test, $p<0.05$ ).

carboxylic acid - ACC) priming increased the germination rate of lettuce seeds (Nascimento et al., 2004), there was no stimulatory effect of ACC priming on seed germination of ryegrass (Tiryaki et al., 2004). This shows that plant responses from ET priming are complex, being species dependent and, according to our results, stress dependent since ET priming resulted in an ameliorative growth in salt stress only (Table 1 ).

MeJA priming can also reduce shoot growth during stress. For instance, Govahi et al. (2007) showed that priming sugar beet seeds with $\mathrm{KNO}_{3}$ plus 1 or $3 \mu \mathrm{M}$ MeJA solutions, improved the percentage emergence at low temperatures. However, the shoot FW and DW of seedlings were reduced when the priming solution contained $\mathrm{KNO}_{3}$ plus 5 or $10 \mu \mathrm{M}$ MeJA, showing the necessity of a clear discrimination between physiological and supra-optimal concentration of MeJA (Govahi et al., 2007). Among the plant hormones tested for seed priming, SA has received considerable attention. For instance, SA not only improved the final germination count but also reduced the germination time of Triticum aestivum under saline conditions (Afzal et al., 2006). SA also increased the DW of wheat roots and shoots (Hamid et al., 2008) and Vicia faba (Azooz, 2009) under salt stress conditions. In contrast, we could not detect any improvement of maize seedling growth subjected to salt stress following SA priming (Table 1).

Compared to NP and $\mathrm{H}_{2} \mathrm{O}$ priming, a slight increase in MDA, an important indicator of the stress state of the cell, was observed in the salt treatment following ET priming and under control growth conditions following SA priming (Figure 2A). However, another compound that may also be an indicator of stress, $\mathrm{H}_{2} \mathrm{O}_{2}$ (Gratão et al., 2005; Scandalios, 2005), was increased under control growth condition following MeJA treatment (Figure 2B). Such an increase in $\mathrm{H}_{2} \mathrm{O}_{2}$ might be the result of increased SOD activity, an enzyme that dismutates $\mathrm{O}_{2}^{-}$to $\mathrm{H}_{2} \mathrm{O}_{2}$, or even, due to a reduction in CAT and APX activities, since the $\mathrm{H}_{2} \mathrm{O}_{2}$ is metabolized by these two enzymes. However, under control growth condition MeJA did not induce SOD (Figure 3A) and did not reduce CAT (Figure 3B) or APX activity (Figure 3C).

As already discussed, SA did not improve maize seedling growth under salt stress (Table 1). Moreover, SA reduces MDA after the priming of faba bean under saline conditions (Azooz, 2009), which again was not observed in maize seedlings under the same conditions in this study (Figure 2A). SOD activity results in the production of $\mathrm{H}_{2} \mathrm{O}_{2}$, which may
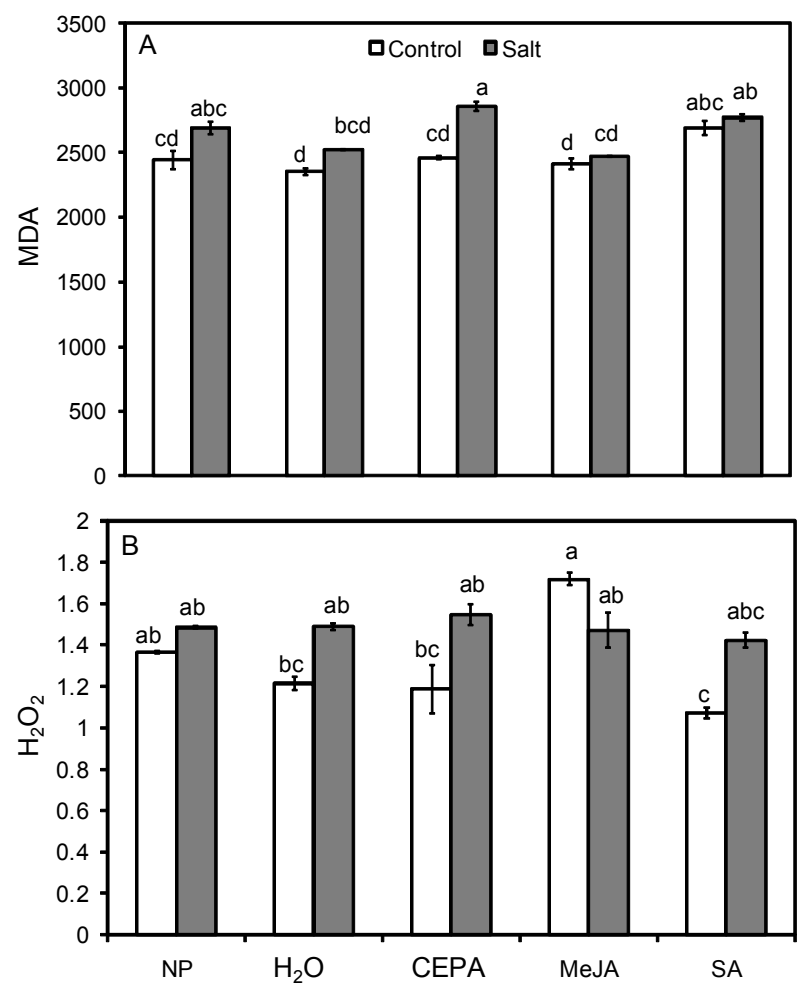

Figure 2-Lipid peroxidation measured as malondialdehyde (MDA) content $\left(\mathrm{nmol} \mathrm{g}{ }^{-1} \mathrm{FW}\right)(\mathrm{A})$ and hydrogen peroxide $\left(\mathrm{H}_{2} \mathrm{O}_{2}\right)$ content $\left(\mu \mathrm{mol} \mathrm{g}^{-1} \mathrm{FW}\right)(\mathrm{B})$, of the shoots of seedlings grown in water (control) or salt $(30 \mathrm{mM} \mathrm{NaCl})$ conditions following priming with water $\left(\mathrm{H}_{2} \mathrm{O}\right)$, chloroethylphosphonic acid (CEPA), methyl jasmonate (MeJA), salicylic acid (SA) or non-primed (NP). Values are the means of three replicates \pm SEM. Different letters indicate differences among treatments (Tukey test, $p<0.05)$.

then be decomposed by the action of peroxidases. SA did not affect $\mathrm{H}_{2} \mathrm{O}_{2}$ production (Figure 2B) or SOD activity (Figure $3 \mathrm{~A}$ ), under either salt or control growth conditions, but increased CAT activity in the control seedlings was observed (Figure 3B). On the other hand, the other peroxidase measured, APX (Figure 3C), and GR (Figure 3D), an important enzyme of the ascorbate-glutathione cycle, which is involved in responses to oxidative stress in distinct organisms (Monteiro et al., 2011; Martins et al., 2011), did not exhibit any change under the tested conditions. Since SA application 

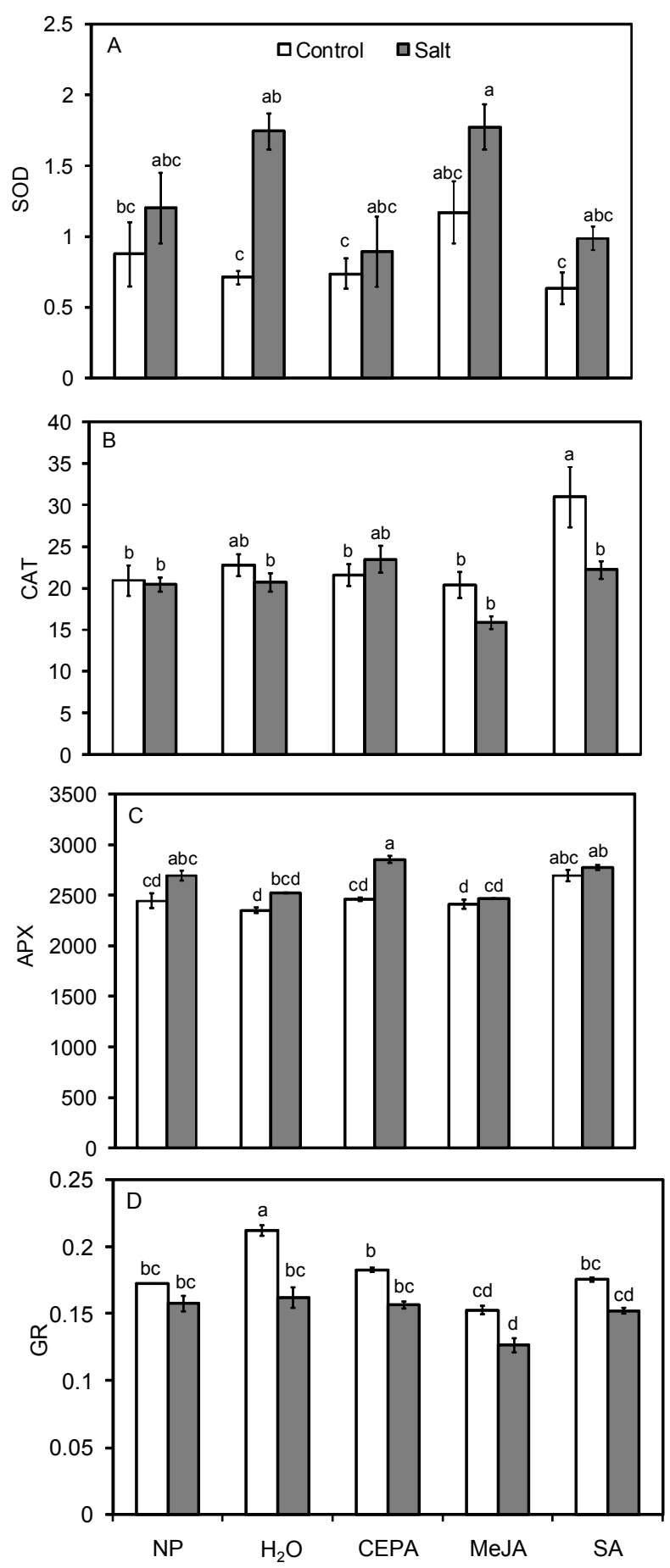

Figure 3 - Specific activity of antioxidant enzymes: (A) superoxide dismutase (SOD) (units $\mathrm{mg}^{-1}$ protein), (B) catalase

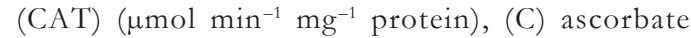
peroxidase (APX) (nmol ascorbate $\mathrm{min}^{-1} \mathrm{mg}^{-1}$ protein) and (D) glutathione reductase (GR) $\left(\mu \mathrm{mol} \mathrm{min}{ }^{-1} \mathrm{mg}^{-1}\right.$ protein) activities of the shoots of seedlings grown in water (control) or salt $(30 \mathrm{mM} \mathrm{NaCl})$ conditions, following priming with water $\left(\mathrm{H}_{2} \mathrm{O}\right)$, chloroethylphosphonic acid (CEPA), methyl jasmonate (MeJA), salicylic acid (SA) or non-primed (NP). Values are the means of three replicates \pm SEM. Different letters indicate differences among treatments (Tukey test, $p<0.05)$. during seed priming has been associated with enhanced SOD, CAT, and APX activities in maize under chilling stress (Farooq et al., 2008), our results with SA priming under salt stress suggest that SA priming, at least in maize, may be a much more complex process.

Hormonal priming of maize seeds does not increase antioxidant enzyme activity, although ET priming has improved the growth of seedlings under salt stress conditions. Currently, a major effort in our laboratory is devoted to obtaining a better understanding of hormonal modulation, with special attention being paid to the action of ET, in maize plants exposed to a wide range of abiotic stresses, in particular those of toxic metals.

\section{Acknowledgements}

This work was funded by FAPESP - Grant $n^{\circ}$. 09/546760. We thank CNPq-Brazil (R.A.A., F.A.P. and D.S.) and FAPESP (L.P.P. and C.C.M.) for the granted fellowships and scholarships.

\section{References}

Afzal, I.; Basra, S.M.A.; Farooq, M.; Nawaz, A. 2006. Alleviation of salinity stress in spring wheat by hormonal priming with $\mathrm{ABA}$, salicylic acid and ascorbic acid. International Journal of Agriculture and Biology 8: 23-28.

Afzal, I.; Basra, S.M.A.; Shahid, M.; Farooq, M.; Saleem, M. 2008. Priming enhances germination of spring maize (Zea mays L.) under cool conditions. Seed Science and Technology 36: 497-503.

Alexieva, V.; Sergiev, I.; Mapelli, S.; Karanov, E. 2001. The effect of drought and ultraviolet radiation on growth and stress markers in pea and wheat. Plant, Cell \& Environment 24: 1337-1344.

Andrews, M.; Lea, P.J.; Raven, J.A.; Azevedo, R.A. 2009. Nitrogen use efficiency. 3. Nitrogen fixation: genes and costs. Annals of Applied Biology 155: 1-13.

Azooz, M.M. 2009. Salt stress mitigation by seed priming with salicylic acid in two faba bean genotypes differing in salt tolerance. International Journal of Agriculture and Biology 11: 343-350.

Bajehbaj, A.A. 2010. The effects of $\mathrm{NaCl}$ priming on salt tolerance in sunflower germination and seedling grown under salinity conditions. African Journal of Biotechnology 9: 1764-1770.

Bernstein, N.; Kravchik, M.; Dudai, N. 2010. Salinity-induced changes in essential oil, pigments and salts accumulation in sweet basil (Ocimum basilicum) in relation to alterations of morphological development. Annals of Applied Biology 156: 167-177.

Bradford, M.M. 1976. A rapid and sensitive method for the quantitation of microgram quantities of protein utilizing the principle of protein-dye binding. Analytical Biochemistry 72: 248-254.

Cartes, P.; Jara, A.A.; Pinilla, L.; Rosas, A.; Mora, M.L. 2010. Selenium improves the antioxidant ability against aluminium-induced oxidative stress in ryegrass roots. Annals of Applied Biology 156: 297-307.

Eisvand, H.R.; Tavakkol-Afshari, R.; Sharifzadeh, F.; Maddah Arefi, H.; Hesamzadeh Hejazi, S.M. 2010. Effects of hormonal priming and drought stress on activity and isozyme profiles of antioxidant enzymes in deteriorated seed of tall wheatgrass (Agropyron elongatum Host). Seed Science and Technology 38: 280-297.

Farooq, M.; Aziz, T.; Basra, S.M.A.; Cheema, M.A.; Rehman, H. 2008. Chilling tolerance in hybrid maize induced by seed priming with salicylic acid. Journal of Agronomy and Crop Science 194: 161168.

Finch-Savage, W.E.; Leubner-Metzger, G. 2006. Seed dormancy and the control of germination. New Phytologist 171: 501-523.

Giannopolitis, C.N.; Ries, S.K. 1977. Superoxide dismutases. I. Occurrence in higher plants. Plant Physiology 59: 309-314. 
Gomes-Júnior, R.A.; Moldes, C.A.; Delite, F.S.; Pompeu, G.B.; Gratão, P.L.; Mazzafera, P.; Lea, P.J.; Azevedo, R.A. 2006a. Antioxidant metabolism of coffee cell suspension cultures in response to cadmium. Chemosphere 65: 1330-1337.

Gomes-Júnior, R.A.; Moldes, C.A.; Delite, F.S.; Gratão, P.L.; Mazzafera, P.; Lea P.J.; Azevedo, R.A. 2006b. Nickel elicits a fast antioxidant response in Coffea arabica cells. Plant Physiology and Biochemistry 44: 420-429.

Gomes-Júnior, R.A.; Gratão, P.L.; Gaziola, S.A.; Mazzafera, P.; Lea, P.J.; Azevedo, R.A. 2007. Selenium-induced oxidative stress in coffee cell suspension cultures. Functional Plant Biology 34: 449-456.

Govahi, M.; Arvin, M.J.; Saffari, G. 2007. Incorporation of plant growth regulators into the priming solution improves sugar beet germination, emergence and seedling growth at low-temperature. Pakistan Journal of Biological Sciences 10: 3390-3394.

Gratão, P.L.; Polle, A.; Lea, P.J.; Azevedo, R.A. 2005. Making the life of heavy metal stressed plants a little easier. Functional Plant Biology 32: 481-494.

Gratão, P.L.; Monteiro, C.C.; Antunes, A.M.; Peres, L.E.P.; Azevedo, R.A. 2008. Acquired tolerance of tomato (Lycopersicon esculentum cv. Micro-Tom) plants to cadmium-induced stress. Annals of Applied Biology 153: 321-333.

Guan, Y.J.; Hu, J.; Wang, X.J.; Shao, C.X. 2009. Seed priming with chitosan improves maize germination and seedling growth in relation to physiological changes under low temperature stress. Journal of Zhejiang University-Science B 10: 427-433.

Hamid, M.; Ashraf, M.Y.; Khalil Ur, R.; Arashad, M. 2008. Influence of salicylic acid seed priming on growth and some biochemical attributes in wheat grown under saline conditions. Pakistan Journal of Botany 40: 361-367.

Heath, R.; Packer, L. 1968. Photoperoxidation in isolated chloroplasts. I. Kinetics and stoichiometry of fatty acid peroxidation. Archives of Biochemistry and Biophysics 125: 189-198.

Iqbal, M.; Ashraf, M. 2007. Seed treatment with auxins modulates growth and ion partitioning in salt-stressed wheat plants. Journal of Integrative Plant Biology 49: 1003-1015.

Martins, P.F.; Carvalho, G.; Gratão, P.L.; Dourado, M.N.; Pileggi, M.; Araujo, W.L.; Azevedo, R.A. 2011. Effects of the herbicides acetochlor and metolachlor on antioxidant enzymes in soil bacteria. Process Biochemistry 46: 1186-1195.

Monteiro, C.C.; Carvalho, R.F.; Gratão, P.L.; Carvalho, G.; Tezotto, T.; Medici, L.O.; Peres, L.E.P.; Azevedo, R.A. 2011. Biochemical responses of the ethylene-insensitive Never ripe tomato mutant subjected to cadmium and sodium stresses. Environmental and Experimental Botany 71: 306-320.
Munns, R.; Tester, M. 2008. Mechanisms of salinity tolerance. Annual Review of Plant Biology 59: 651-681.

Nakano, Y.; Asada, K. 1981. Hydrogen peroxide is scavenged by ascorbate-specific peroxidase in spinach chloroplasts. Plant and Cell Physiology 22: 867-880.

Nascimento, W.M.; Cantliffe, D.J.; Huber, D.J. 2004. Ethylene evolution and endo-â-mannanase activity during lettuce seed germination at high temperature. Scientia Agricola 61: 156-163.

Sarlikioti, V.; Driever, S.M.; Marcelis, L.F.M. 2010. Photochemical reflectance index as mean of monitoring early water stress. Annals of Applied Biology 157: 81-89.

Scandalios, J.G. 2005. Oxidative stress: molecular perception and transduction of signals triggering antioxidant gene defenses. Brazilian Journal of Medical and Biological Research 38: 9951014.

Soccio, M.; Laus, M.; Spera, G.; Trono, D.; Pompa, M.; Flagella, Z.; Pastore, D. 2010. Mitochondrial proline oxidation is affected by hyperosmotic stress in durum wheat seedlings. Annals of Applied Biology 157: 1-11.

Teklic, T.; Hancock, J.T.; Engler, M.; Paradikovic, N.; Cesar, V.; Lepedus, H.; Stolfa. I. Beslo, D. 2008. Antioxidative responses in radish (Raphanus sativus L.) plants stressed by copper and lead in nutrient solution and soil. Acta Biologica Cracoviensia Series Botanica 50: 79-86.

Tiryaki, I.; Korkmaz, A.; Ozbay, N.; Nas, M.N. 2004. Priming in the presence in the plant growth regulators hastens germination and seedling emergence of dormant annual ryegrass (Lilium multiflorum Lam.) seeds. Asian Journal of Plant Science 3: 655659.

Zhang, S.; Hu, J.; Zhang, Y.; Xie, X.J.; Knapp, A. 2007. Seed priming with brassinolide improves lucerne (Medicago sativa L.) seed germination and seedling growth in relation to physiological changes under salinity stress. Australian Journal of Agricultural Research 58: 811-815.

Received January 06, 2011

Accepted March 17, 2011 